\title{
DISKUSI KELOMPOK TERARAH MEKANISME PENGELOLAAN DAN AKUNTABILITAS DANA DESA, DESA SEBONG LAGOI KECAMATAN TELUK SEBONG KABUPATEN BINTAN
}

\author{
Focus Group Discussion (FGD) \\ Management Mechanism And Accountability Of Village Funds, \\ Sebong Lagoi Village Teluk Sebong District Subdistrict Bintan
}

\author{
Akhirman $^{* 1)}$, Winata Wira ${ }^{1)}$ \\ 1) Fakultas Ekonomi Universitas Maritim Raja Ali Haji, Tanjungpinang \\ *Korespondensi : 4akhirman@gmail.com
}

\begin{abstract}
ABSTRAK
Desa Sebong Lagoi merupakan desa yang dipilih sebagai lokasi tempat kegiatan Pengabdian Kepada Masyarakat, selain sebagai desa penerima Dana Desa, Dan satu dari 36 Desa yang ada di Kabupaten Bintan. Kegiatan dilaksanakan dalam bentuk kegiatan Penyuluhan tentang, "Mekanisme Pengelolaan dan Akuntabilitas Dana Desa. Metode yang digunakan bertentuk ceramah, tanya jawab, antara narasumber dengan peserta. Peserta mendapatkan penjelasan berkaitan dengan Fungsi dan Peran Pengelolaan Dana Desa, Akuntabilitas (Pertanggungjawaban), serta kondisi penyerapan dana desa per proivinsi di Indonesia dari tahun 2015-2017. Terahir kami sampaikan ucapan terimakasih kepada Rektor UMRAH dan LP3M yang telah menyediakan anggaran untuk pelaksanaan kegiatan Pengabdian Kepada Masyaraka, sehingga dosen melaksanakan kegiatan tersebut sesuai rencana.
\end{abstract}

Kata Kunci : Pengelolaan dana desa, Pengabdian Kepada Masyarakat.

\begin{abstract}
Sebong Lagoi Village is the village that has been chosen the location for community service, aside from being as the village funds, as one of 36 village in Bintan. The activities are carried out in the form of counseling about "Fund management Mechanism and Accountability of village funds" The method used is in the form lectures, question and answer between resource person and partisipants. Participants get an explanation related to functions and roles of village fund management, accountability, as well as conditions for the absorption of village funds for every province in Indonesia from 2015-017. Finally, we would like to thank the UMRAH chancellor and LP3M for providing the budget for the implementing community service antivities so that the lectures are able to carry on the activity according to plan.
\end{abstract}

Keywords: Village fund management, community service. 


\section{PENDAHULUAN}

Pengelolaan Dana Desa yang baik dan benar memiliki keterkaitan dengan upaya pengembamgan Potensi kekayaan alam khususnya di Provinsi Kepulauan Riau yang dikarunia Tuhan Yang Maha Esa untuk kemakmuran masyarakat dan dikelola dengan sebaik-baiknya. Bersumber dari pertambangan dan industri pengolahan, sektor pertanian, perkebunan, dan kehutanan, sektor perikanan, sektor pariwisata (BPS Kepri : 2015), sampai saat ini masih sangat menjanjikkan dan memerlukan peran masyarakat yang kreatif dan inovatif dalam pengelolaannya agar bermanfaat untuk masyrakat itu sendiri.

Dana Desa adalah dana yang bersumber dari Anggaran Pendapatan dan Belanja Negara yang diperuntukkan bagi Desa dan Desa Adat yang di transfer melalui Anggaran Pendapatan dan Belanja Daerah kabupaten/kota dan digunakan untuk membiayai penyelenggaraan pemerinthan, pembangunan serta pemberdayaan masyarakat dan kemasyarakatan. Sesuai dengan amanat Undang-Undang Nomor 6 tahun 2014 tentang Desa. Pemerintah mengalokasikan Dana Desa, melalui mekanisme transfer kepada Kabupaten/Kota berdasarkan alokasi dana tersebut. Maka tiap kabupaten/kota mengalokasikannya kepada setiap desa berdasarkan jumlah desa dengan memperhatikan jumlah penduduk (30\%), Ulas Wilayah (20\%), dan angka Kemiskinan (50\%), hasil perhitungan tersebut disesuaikan juga dengan tingkat kesulitan geografis masing-masing desa.

Pemerintah Pusat melalui Nawacita berkomitmen untuk membangun Indonesia dari pinggiran (Dokumen RPJMD Kepri, 2015), dengan cara meningkatkan pembangunan di desa melalui program Dana Desa. Dalam pelaksanaannya Dana Desa ini dialokasikan guna mendukung pelaksanaan tugas dan fungsi desa dalam penyelenggaraan pemerintahan dan pembangunan desa dalam segala aspeknya. Selain misi pembangunan juga berdampak pada peningkatan aktivitas dan partisipasi masyarakat desa untuk turut membangun desanya dan bagian dari pemberdayaan SDM-Desa.

Permasalahan yang terjadi dan mengharuskan pemerintah pusat melakukan evaluasi bahkan telah memangkas sebesar Rp. 600 juta dari Rp. 31,5 miliar pada APBN 2017. Disebabkan kendalahkendala yang dihadapi oleh pengelola Dana Desa selama ini. Kendala yang mereka alami adalah; (1) Masih rendahnya pemahaman tentang tujuan dan fungsi Dana Desa. (2) Belum menguasai secara baik tentang prosedur dan pengelolaan Dana Desa. (3) Kurangnya koordinasi, singkroniasi pengelolaan Dana Desa.(4) Belum transfarannya pengelolaan Dana Desa. (5) Masih kurangnya motivasi membangun desa dari masyarakat untuk masyarakat.

Dengan pemikiran di atas, maka kami tergerak untuk melaksanakan kegiatan Pengabdian Kepada Masyarakat dalam bentuk penyuluhan dengan materi; "Mekanisme Pengelolaan dan Akuntabilitas Dana Desa. Indikator pencapaian PKM yang di harapkan dari kegiatan ini adalah :

1. Semua pengguna dana desa di Kabupaten Bintan khususnya dapat terlaksana sesuai ketentuan yang berlaku.

2. Efektivitasnya penggunaan Dana Desa dan program yang dikerjakan sesuai tujuan dan fungsinya baik dirasakan oleh masyarakat lingkungan maupun oleh pemerintah daerah dan pemerintah pusat.

3. Terhindarnya para pelaksana dari jeratan hukum baik sanksi administrative maupun pidana..

4. Tahun berikutnya diharapkan pengabdian kepada masyarakat di Kabupaten Bintan mampu mencapai 60 persen. 


\section{METODE}

\section{Waktu dan Tempat}

Kegiatan Pengabdian kepada masyarakat dilaksanakan pada hari Senin, 3 September 2018 bertempat di Balai Desa Sebong Lagoi Kecamatan Teluk Sebong Kabupaten Bintan. Dengan rangkaian kegiatan sebagai berikut. Pesera dari perangkat desa, petugas pengelola dana desa, unsur organiasi PKK, Karang Taruna, Tokoh Masyarakat.

\section{Metode Pelaksanaan dan Analisis Data}

Metode yang digunakan pada kegiatan ini dibagi kepada tiga tahapan, yaitu; Persiapan, Pelaksanaan dan Evaluasi.

\section{Persiapan awal.}

Pada tahap ini melakukan Survey awal lokasi, mempelajari dinamika pengelolaan Dana Desa tahun 2017, baik yang berhasil mapun yang belum, melakukan penawaran untuk membantu memberikan pembekalan/pengetahuan melalui program Pengabdian Kepada Masyarakat, mentapkan Lokasi, audiensi dan tempat kegiatan, serta menerbitkan dokumen

kerjsama. mempersiapn surat undangan untuk perangkat desa, instansi terkait, tokoh masyarakat, organiasi kepemudaan, organisasi kewanitaan, dan pelaksana program.

\section{Pelaksanaan kegiatan}

Kegiatan di buat dalam bentuk Ceramah, diskusi, tanya jawab, serta penyerapan informasi, yang berkaitan dengan, "Mekaniske Pengelolaan dan Akuntabilitas Dana Desa." Selain materi tersebut juga disampaikan materi motivasi membangun desa yang di harapkan agar menjadi desa mandiri.

\section{Tahap evaluasi}

Tahapan evaluasi ada dua kategori, yaitu evaluasi efektivitas dari kegiatan tersebut dan impac yang di berikan dari kegiatan tersebut terhadap peserta dapat diperoleh melalui informasi, komunikasi dan interaksi secara berkala.

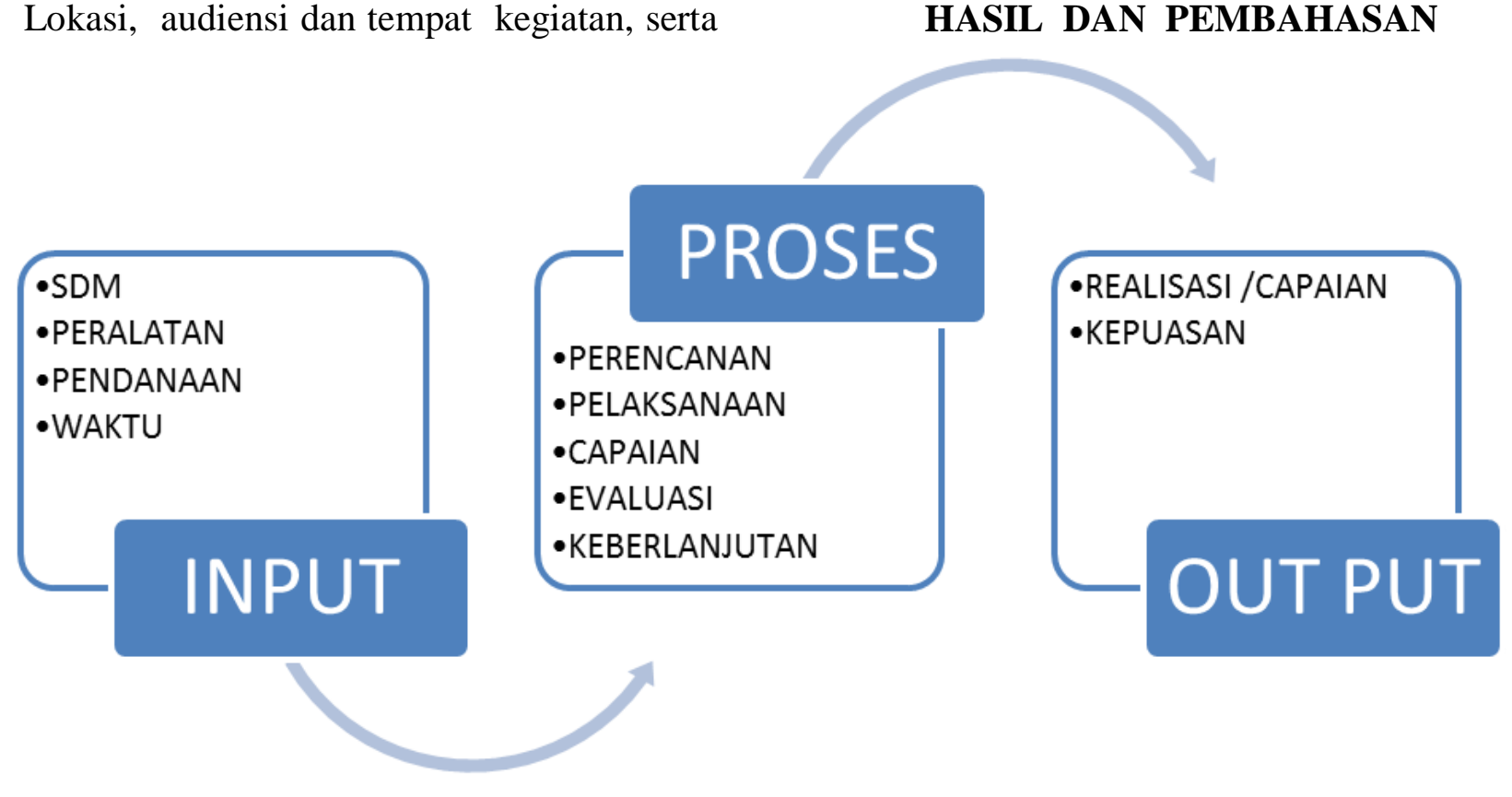

Gambar 1 Tahapan Pelaksanaan Program 
Acara berlangsung dengan baik dan lancar banyak hal kebijakan-kebijakan yang berkaitan dengan pengelolaan dana desa yang harus di jelaskan dan di sederhanakan agar pengelolaannya benarbenar dirasakan manfaatnya oleh masyarakat.

Menurut

Harsoyo

$(1977: 121)$

Pengelolaan adalah serangkaian usaha yang bertujuan untuk menggali dan memanfaatkan segala potensi yang dimiliki secara efektif dan efisien guna mencapai tujuan tertentu yang telah direncanakan sebelumnya. Permendagri RI. Nomor 37 tahun 2007 Menyebutkan pengelolaan keuangan desa adalah keseluruhan kegiatan yang meliputi perencanaan, penganggaran, penatausahaan, pelaporan, pertanggungjawaban dan pengawasan keuangan desa.

Akuntabilitas berisikan prinsip-prinsip yang mana setiap kegiatan yang pendanaannya di ambil dari dana desa harus diawali dari perencanaan, pelaksanaan dan evaluasi secara terbuka dengan prinsip dari, oleh dan untuk masyarakat. Seluruh kegiatan dan penggunaan anggaran dana desa harus dapat dipertangungjawabkan secara administrasi, teknis dan hukum. Alokasi dana desa harus digunakan dengan prinsip, hemat terarah dan terkendali.

Tingkat pertumbuhan ekonomi Provinsi Kepulauan Riau saat ini sedikit mengalami penurunan dibandingkan tahun 2014 dimana pertumbuhan ekonomi mencapai 7,2 persen namun dari tahun 2015 hingga tahun 2017 pertumbuhan ekonomi di Kepulauan Riau mengalami penurunan yang cukup drastis hingga mencapai 2,02 persen (BPS-Kepri : 2015). Hal ini disebabkan terjadinya krisis global di alami oleh negara-negara yang terintegrasi secara bersma-sama dalam kegiatan ekonomi secara umum mengalami dampaknya, termasuk Provinsi Kepulauan Riau sebagai kawasan yang berbatasan langsung dengan Negara Malaysia dan
Singapura sebagai bagian dari negara tujuan ekspor komoditas sektor Industri galangan kapal, elektronik berdampak lesu pada sektor lainnya seperti pertanian dan pariwisata.

Pengelolaan Dana Desa dimulai dari rumusan Input (SDM, Peralatan, Pendanaan dan Waktu. Proses melalui tahapan Perencanaan, Pelaksanaan, Capakaian, Evaluasi, dan Keberlanjutan. Serta Out Put dengan realisasi/capaian berupa Fisik hasil kegiatan yang dirasakan oleh masyarakat.

Penyerapan dana desa di Kabupaten Bintan untuk 36 desa menyerapannya mencapai 89 persen dari sumber dana APBN tahap I tahun 2017. Dengan program Pembangunan sebgai berikut:

1) Jalan desa $22.897 \mathrm{~km}$,

2) Drainase $444,3 \mathrm{~km}$,

3) Jembatan $15 \mathrm{~m}$,

4) Tembok penahan tanah $625 \mathrm{~m}$, dan

5) 11 unit Pos Yandu. Kemudian

6) 15 unit Paud,

7) 15 unit Kios Internet,

8) Penyediaan Air Bersih 13 unit dan

9) 5 Taman Belajar.

\section{KESIMPULAN}

Dengan pelaksanan kegiatan tersebut dapat dikatakan bahwa pelaksanaan dan sasaran serta tujuan kegiatan ini dapat diterima dengan senang hati oleh pemerintahan dan masyarakat desa. Selain memberikan informasi juga mendorong keterlibatan masyarakat lebih luas terhadap program pembangunan desa melalui dana desa. Diharapkan kepada perangkat desa untuk kegiatan serupa agar lebih termotivasi untuk mengikutinya, karena selain menambah informasi, pengetahuan, juga menjadi acuan terhadap pelaksanaan kegiatan pengelolaan dana desa yang lebih bermanfaat terarah dan akuntabilias. 


\section{DAFTAR PUSTAKA}

[BPS] Badan Pusat Statistik Kepulauan Riau. 2015. Profil Kabupaten Bintan. Kepulauan Riau : Badan Pusat Statistik

Dokumen RPJMD Kepulauan Riau. 2015. Program Pembangunan di Provinsi Kepulauan Riau.
Hasibuan, Melayu S.P. 1991. Manajemen Sumber Daya Manusia Dasar, dan Kunci Keberhasilan, Jakarta : CV. Haji Mas Agung.

PMK 225/PMK.07/2017 Tentang perubahan kedua atas Peraturan Menteri Keuangan Nomor 50/PMK.07/2017 Tentang Pengelolaan Dana Desa

Diterima : 5 September 2018

Disetujui : 8 November 2018 